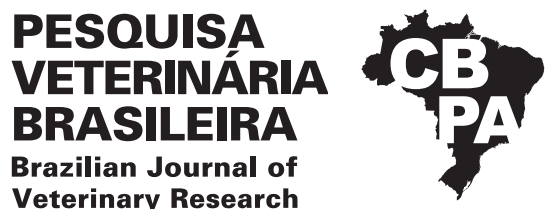

Pesq. Vet. Bras. 40(5):346-354, May 2020 DOI: 10.1590/1678-5150-PVB-6540

Original Article

Veterinarv Research

ISSN 0100-736X (Print)

Livestock Diseases

ISSN 1678-5150 (Online)

\title{
Cerebrospinal fluid analysis in 58 ruminants showing neurological disorders ${ }^{1}$
}

\author{
Antônio Carlos L. Câmara ${ }^{2 *}$ (D), Mariana C. Gonzaga², Thaís M. Ziober², \\ Cintia Regina R. Queiroz ${ }^{3}$, Tayná C.M. Fino², Márcio B. Castro ${ }^{3}$, \\ José Renato J. Borges ${ }^{2}$ and Benito Soto-Blanco ${ }^{4}$
}

\begin{abstract}
Câmara A.C.L., Gonzaga M.C., Ziober T.M., Queiroz C.R.R., Fino T.C.M., Castro M.B., Borges J.R.J. \& Soto-Blanco B. 2020. Cerebrospinal fluid analysis in 58 ruminants showing neurological disorders. Pesquisa Veterinária Brasileira 40(5):346-354. Hospital Escola de Grandes Animais, Universidade de Brasília, Área Especial SRB, Galpão 4, Granja do Torto, DF 70636-200, Brazil. E-mail: aclcamara@yahoo.com.br

Ruminants may be affected by a wide variety of central nervous system (CNS) diseases. Cerebrospinal fluid (CSF) analysis forms the basis for ante mortem diagnostic evaluation of ruminants with clinical signs involving the CNS. Despite its importance as a tool to aid diagnosis, data regarding CSF examinations in spontaneous cases of CNS diseases in ruminants from Brazil are limited, and most reports involve experimental studies. Therefore, this study aimed to report the results of CSF analysis in 58 ruminants showing signs of neurological disorders. CSF samples for analysis were obtained from 32 cattle, 20 sheep, and 6 goats by cerebellomedullary cistern $(n=54)$ or lumbosacral space $(n=4)$ puncture. These ruminants showed neurological signs related to viral $(n=13)$, mycotic $(n=3)$, or bacterial $(n=15)$ infections, and toxic $(n=21)$, traumatic $(n=4)$, or congenital disorders $(n=2)$. CSF analysis from ruminants with viral infections presented lymphocytic pleocytosis, even though CSF showed no changes in several cases of rabies. Neutrophilic pleocytosis, cloudiness, presence of fibrin clots, and abnormal coloration were evident in the CSF of most cases of CNS bacterial infection, such as meningoencephalitis, meningitis, abscesses, myelitis, and a case of conidiobolomycosis. On the other hand, CSF was unchanged in most cases of toxic disorders, as botulism and hepatic encephalopathy. Elevated CSF density was observed in $60 \%$ of ruminants diagnosed with polioencephalomalacia. Our findings show that evaluation of CSF is a valuable diagnostic tool when used in association with epidemiological, clinical and pathological findings for diagnosis of CNS diseases in ruminants.
\end{abstract}

INDEX TERMS: Cerebrospinal fluid, ruminants, neurological disorders, central nervous system, cytology, liquor, livestock, neurology.

RESUMO.- [Análise do líquido cefalorraquidiano em 58 ruminantes com distúrbios neurológicos.] Os ruminantes podem ser afetados por uma grande variedade de doenças do sistema nervoso central (SNC). A análise do líquido cefalorraquidiano (LCR) constitui a base da avaliação diagnóstica ante mortem de ruminantes com sinais clínicos envolvendo o SNC. Apesar de sua importância como ferramenta para auxiliar no diagnóstico, os dados referentes aos exames do LCR em

\footnotetext{
${ }^{1}$ Received on November 26, 2019.

Accepted for publication on February 17, 2020.

${ }^{2}$ Hospital Escola de Grandes Animais, Faculdade de Agronomia e Medicina Veterinária (FAV), Universidade de Brasília (UnB), Área Especial SRB, Galpão 4, Granja do Torto, DF 70636-200, Brazil. *Corresponding author: aclcamara@yahoo.com.br
}

casos espontâneos de doenças do SNC em ruminantes no Brasil são limitados, e, a maioria dos relatos envolve estudos experimentais. Portanto, este trabalho teve como objetivo relatar os resultados da análise do LCR em 58 ruminantes com distúrbios neurológicos. Amostras do LCR foram obtidas de 32 bovinos, 20 ovinos e 6 caprinos por punção da cisterna cerebelo-medular $(n=54)$ ou espaço lombossacro $(n=4)$ para posterior análise. Esses ruminantes apresentaram

\footnotetext{
${ }^{3}$ Laboratório de Patologia Veterinária, Faculdade de Agronomia e Medicina Veterinária (FAV), Universidade de Brasília (UnB), Via L4 Norte s/n, Asa Norte, Brasília, DF 70910-970, Brazil.

${ }^{4}$ Departamento de Clínica e Cirurgia Veterinárias, Escola de Veterinária, Universidade Federal de Minas Gerais (UFMG), Av. Pres. Antônio Carlos 6627, Belo Horizonte, MG 30123-970, Brazil.
} 
sinais neurológicos relacionados a infecções virais $(n=13)$, micóticas $(n=3)$ ou bacterianas $(n=15)$, e desordens tóxicas $(n=21)$, traumáticas $(n=4)$ ou congênitas $(n=2)$ A análise do LCR de ruminantes com infecções virais apresentou pleocitose linfocítica, embora, em vários casos de raiva, o LCR não tenha apresentado alterações. Pleocitose neutrofílica, turbidez, presença de coágulos de fibrina e coloração anormal foram evidentes no LCR da maioria dos casos de infecções bacterianas do SNC, como meningoencefalites, meningites, abscessos, mielite e um caso de conidiobolomicose. Por outro lado, o LCR não foi alterado na maioria dos casos dos distúrbios tóxicos, como botulismo e encefalopatia hepática. A densidade elevada no LCR foi observada em $60 \%$ dos ruminantes diagnosticados com polioencefalomalácia. Nossos resultados mostram que a avaliação do LCR é uma valiosa ferramenta de diagnóstico, quando usada em associação com os achados epidemiológicos, clínicos e patológicos para o diagnóstico de doenças do SNC em ruminantes.

TERMOS DE INDEXAÇÃO: Líquido cefalorraquidiano, ruminantes, distúrbio neurológico, animais de produção, citologia, líquor, neurologia, sistema nervoso central.

\section{INTRODUCTION}

Ruminants may be affected by a wide variety of central nervous system (CNS) diseases, including bacterial, viral, and protozoal infections, poisonings, metabolic disorders, trauma, and neoplasms (Scott 2004, Mayhew 2009). Neurological disorders have a noteworthy incidence in ruminants, as observed in retrospective studies conducted in cattle presenting clinical signs of neurological disorders from the Brazilian states of Rio Grande do Sul, Mato Grosso do Sul, and Paraíba, achieving prevalence of $9.16 \%$ (552/6,021 cases), 31.5\% (341/1,082 cases), and 33.8\% (139/411 cases), respectively (Sanches et al. 2000, Galiza et al. 2010, Ribas et al. 2013).

Cerebrospinal fluid (CSF) analysis forms the basis for ante mortem diagnostic evaluation of ruminants with clinical signs involving the CNS. This complementary test can assist in determining a conclusive diagnosis, obtaining samples for other diagnostic tests (microbiological culture or viral isolation), or as an aid to monitor treatment response (Mayhew 2009, Stokol et al. 2009, Nagy 2017). In ruminants, CSF is easily and safely obtained, in most cases, through cerebellarmedullary (cisterna magna) or lumbosacral puncture (Scott 2010, Nagy 2017).

Despite its importance as a tool to aid diagnosis, data regarding CSF examinations in spontaneous cases of CNS diseases in ruminants from Brazil are limited (Lisbôa et al. 1996, Della Libera et al. 2004, Câmara et al. 2009, 2011, 2014a, 2014b, 2014c, Queiroz et al. 2018, Moreira et al. 2018), and most reports involve experimental studies (Lisbôa et al. 2009, Batista et al. 2011, Cunha et al. 2011, Isernhagen et al. 2011). Therefore, this study aimed to report the results of CSF analysis in 58 ruminants showing signs of neurological disorders.

\section{MATERIALS AND METHODS}

Clinical records of ruminants from two referring hospitals (Veterinary Hospital of the "Universidade Federal Rural do Semi-Árido", Mossoró/ RN, and Large Animal Veterinary Teaching Hospital of "Universidade de Brasília”, Brasília/DF, Brazil) with CSF analysis records were evaluated. Information retrieved included epidemiological, laboratory, and conclusive diagnosis data. Thirty-two cattle, 20 sheep, and 6 goats were included in the study, totaling 58 ruminants. Criteria for inclusion of cases was a conclusive diagnosis based on a combination of epidemiological, clinical, laboratory, and pathological evaluation. Cases of rabies were also confirmed by gold-standard methods (direct immunofluorescence or mouse inoculation test) in an official government laboratory ("Diretoria de Vigilância Ambiental em Saúde", DIVAL, DF).

CSF samples were collected aseptically by puncturing the cerebellum-medullar cistern $(n=54)$ or lumbosacral space $(n=4)$, and analyzed according to the methodology proposed by Scott (2004, 2010). Erythrocyte and leukocyte counts were performed in a Neubauer chamber. For cytological examination and leukocyte differential counts, a smear of a cell concentrate obtained by centrifugation was stained with Panotic stain (NewProv InstantProv, Pinhais/PR, Brazil). CSF density was obtained by using a clinical refractometer (Quimis, Diadema/SP, Brazil), and protein concentration was determined by a colorimetric method (Katal, Belo Horizonte/ MG, Brazil) using a semi-automated biochemical analyzer (Bioplus BIO-2000, Barueri/SP, Brazil).

CSF aliquots were seeded on defibrinated sheep blood agar (5\%) for microbiological culture, followed by incubation in a bacteriological incubator at $37^{\circ} \mathrm{C}$ for $48 \mathrm{~h}$. Thereafter, we analyzed the macroscopic and morphotintorial characteristics (by Gram staining method), and biochemical profile (MacFaddin 2000). In cases of conidiobolomycosis, CSF and CNS fragments were seeded on Sabouraud Chloramphenicol Agar and incubated at $28^{\circ} \mathrm{C}$ for 7 days (Câmara et al. 2011).

From the 58 ruminants, 31 (53.4\%) died spontaneously and 27 (46.6\%) were submitted to euthanasia in extremis. For pathological evaluation, organ samples were collected according to clinical suspicion and were fixed in $10 \%$ formalin, and then routinely processed for histology and stained using the hematoxylin and eosin (HE) technique.

\section{RESULTS AND DISCUSSION}

Epidemiological data, clinical evolution and conclusive diagnosis from 58 ruminants showing neurological signs are presented at Table 1 . Results of the CSF analyses according to the etiology are summarized in Tables 2 to 5. Microbiological assays were performed on every CSF sample from each case, but, as expected, only bacterial CNS diseases yielded microbiological growth (Table 3).

Eleven cases (18.9\%) of rabies were diagnosed, including one goat (Case 1 ) and 10 cattle (Cases 2-11). In all rabies cases, the common epidemiological background was the absence of preventive vaccination and the presence of hematophagous bats on the farms (Moreira et al. 2018). A conclusive diagnosis of rabies was obtained by histology (Negri's bodies inclusions), immunohistochemistry, or gold-standard methods. Rabies is a viral disease with important zoonotic potential and high lethality (Moreira et al. 2018). In our cases, CSF analysis revealed pleocytosis in 6 of 11 ruminants (54.5\%), with counts of 16-333 leukocytes $/ \mu \mathrm{L}$, mainly involving mononuclear cells. The other five ruminants $(45.5 \%)$ had no CSF changes (leukocytes counts peaked $6 / \mu \mathrm{L}$ ). Despite few reports on CSF findings in rabid ruminants, when mononuclear pleocytosis (mainly lymphocytic) is present, CSF analysis presents as an important ancillary tool for diagnosis and allows exclusion of potential CNS bacterial infections that cause similar 
Table 1. Epidemiological data, clinical evolution, and conclusive diagnosis from 58 ruminants showing neurological signs

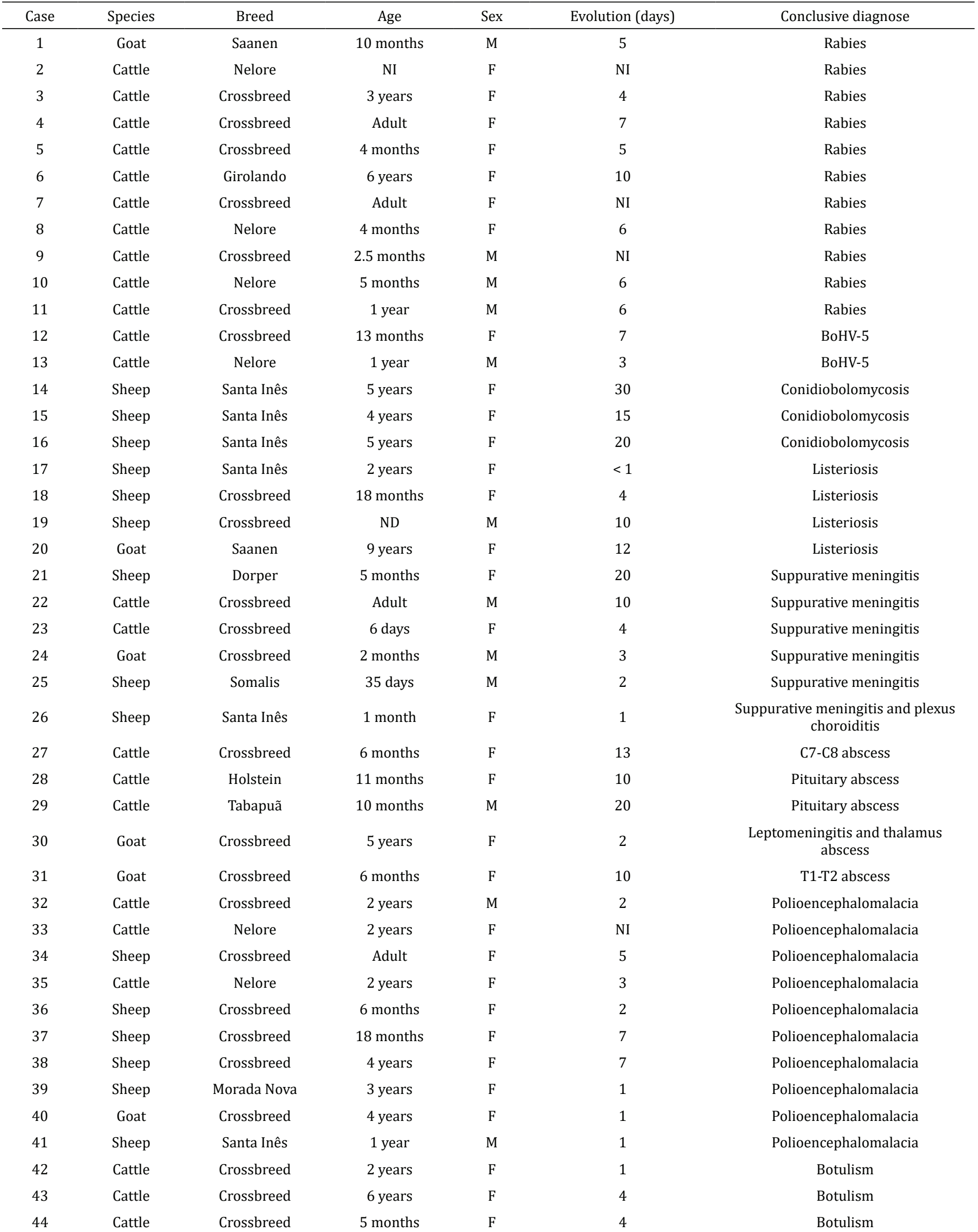




\begin{tabular}{ccccccc}
\hline Case & Species & Breed & Age & Sex & Evolution (days) & Conclusive diagnose \\
\hline 45 & Cattle & Crossbreed & 5 years & F & 3 & Botulism \\
46 & Cattle & Crossbreed & 7 years & F & 3 & Botulism \\
47 & Cattle & Crossbreed & 22 months & M & 2 & Botulism \\
48 & Cattle & Crossbreed & 18 months & M & 3 & Botulism \\
49 & Sheep & Santa Inês & Adult & M & NI & Botulism \\
50 & Sheep & Crossbreed & 15 months & M & 8 & Botulism \\
51 & Sheep & Crossbreed & ND & F & 10 & Botulism \\
52 & Sheep & Santa Inês & 3 years & F & 90 & Poisoning by Brachiaria \\
53 & Sheep & Santa Inês & Adult & F & 6 & Atlanto-axial dislocation \\
54 & Cattle & Nelore & 9 months & M & 6 & C2-C3 fracture \\
55 & Cattle & Nelore & 3 years & F & 4 & T6-T8 fracture \\
56 & Cattle & Nelore & 5 months & F & 7 & Spinal cord compression \\
57 & Cattle & Gir & 2 months & F & Spinal lipomatosis \\
58 & Cattle & Crossbreed & 75 days & F & NI & Cerebellar hypoplasia
\end{tabular}

$\mathrm{NI}=$ not informed, BoHV-5 = bovine herpesvirus 5, $\mathrm{M}=$ male, $\mathrm{F}=$ female.

neurological signs (Moreira et al. 2018), since this finding is typically associated to viral infections (Stokol et al. 2009). Recently, a study evaluating 17 rabid cattle concluded that CSF may not change or may exhibit discrete mononuclear pleocytosis and/or mildly elevated protein within the CSF (Queiroz et al. 2018). Our results reinforce the wide variation of CSF findings reported in rabid ruminants (Queiroz et al. 2018), and reiterate the difficulty of ante mortem diagnosis of this condition. We reinforce rabies zoonotic potential, and suspected cases should be isolated and contact kept to a minimum with only vaccinated humans. Gloves and masks should be worn during examination, samples collection or when performing necropsies (Moreira et al. 2018).

Two sporadic cases of meningoencephalitis caused by bovine herpesvirus 5 (BoHV-5) (Cases 12 and 13) were identified in two 1-year-old Nelore steers. These cases were from large beef herds, mainly feedlot steers, with history of sporadic deaths. Herd management included semiannual deworming and vaccination against foot and mouth disease, rabies, and clostridiosis. Epidemiological background and pathological features are essential for differential diagnosis of BoHV-5 meningoencephalitis vs. rabies, since CSF results may be similar (Lisbôa et al. 2009, Isernhagen et al. 2011, Queiroz et al. 2018). Herein, CSF analysis varied from unchanged (Case 12 ) to a marked mononuclear pleocytosis (304 leukocytes $/ \mu \mathrm{L}$ ) (Case 13). CSF results in BoHV-5 meningoencephalitis are well correlated with the intensity and severity of the inflammatory process in the CNS (Queiroz et al. 2018), which agreed with the clinical evolution and pathological findings in our cases.

CSF analysis from three sheep diagnosed with conidiobolomycosis (Cases 14-16) revealed a range of results, since no CSF changes (Case 14) to the presence of fibrin clots (Case 16), and even alterations normally associated with bacterial infections (cloudy appearance, high protein levels, light yellow coloration, and neutrophilic pleocytosis) (Case 15). Three outbreaks of conidiobolomycosis occurred in the semiarid region of Rio Grande do Norte, Brazil, and affected 22 sheep. Most animals showed the rhinopharyngeal form of the disease, while the rhinocerebral form was diagnosed in these three sheep, which presented neurological signs, macroscopic lesions infiltrating the cribiform plate, frontal and temporal bones, as well as cerebral cortex lesions, and histological findings of meningoencephalitis and malacia (Câmara et al. 2011). However, only the sheep with the most severe lesions (Case 15) presented CSF alterations similar to cases of bacterial meningoencephalitis (Mayhew 2009, Stokol et al. 2009, Câmara et al. 2014a). Although the protein concentration was not determined in two cases, the presence of fibrin clots without CSF color or leukocyte changes in one sheep (Case 16) is strongly associated with high protein levels (Scott 2004). Thus, evaluation of CSF is recommended for determining CNS involvement in cases of conidiobolomycosis (Câmara et al. 2011).

Listeriosis was diagnosed in four cases (Cases 17-20). Three adult sheep showed meningoencephalitis (Cases 1719), while a 9-year-old Saanen doe presented myelitis (Case 20). In all cases, microbiological assays from CSF samples revealed the etiological agent as the Gram-positive bacillus Listeria monocytogenes. One adult sheep (Case 18) was part of a meningoencephalitis outbreak in a large sheep flock receiving silage (Câmara et al. 2014c). The other two affected sheep were sporadic cases from farms located in Distrito Federal (Case 17) and Ceará (Case 19), in Midwestern and Northeastern Brazil, respectively. In two sheep, CSF results revealed a cloudy appearance, yellowish coloration, presence of fibrin clots, slight protein increase, and neutrophilic pleocytosis with 92 (Case 18) and 66 (Case 19) leukocytes/ $\mu \mathrm{L}$, of which $65 \%$ and $80 \%$ consisted of polymorphonuclear cells, respectively. In the other sheep (Case 17), despite the colorless and clear appearance of the CSF, pleocytosis was the highest among cases, but was mainly monocytic. In about $49 \%$ of cattle with listeriosis, mononuclear pleocytosis is observed (Stokol et al. 2009), but this is less common in sheep and goats (Mayhew 2009). In listeriosis, neutrophilic pleocytosis is the most frequently observed change in sheep (Scott 2010). This feature was also observed in listerial myelitis (Case 20), that 
Table 2. Results of cerebrospinal fluid analyses of 16 ruminants showing neurological signs caused by viral (n=13) and mycotic $(n=3)$ diseases

\begin{tabular}{|c|c|c|c|c|c|c|c|c|c|c|}
\hline Disease & Case & Aspect & Color & Density & $\mathrm{pH}$ & $\begin{array}{l}\text { Proteins } \\
(\mathrm{mg} / \mathrm{dl})\end{array}$ & $\begin{array}{l}\text { Glucose } \\
\text { (mg/dl) }\end{array}$ & $\begin{array}{c}\text { Erythrocytes } \\
(/ \mu \mathrm{L})\end{array}$ & $\begin{array}{l}\text { Nucleated } \\
\text { cells }(/ \mu \mathrm{L})\end{array}$ & Pleocytosis \\
\hline \multirow[t]{11}{*}{ Rabies } & 1 & Clear & Colorless & 1.005 & 8 & 46.7 & 146 & 1,242 & 29 & $\begin{array}{l}\text { Lymphocytic (69\%) and } \\
\text { monocytic }(25 \%)\end{array}$ \\
\hline & 2 & Clear & Colorless & 1.008 & 8 & 34.8 & 95 & 2 & 32 & Lymphocytic \\
\hline & 3 & Clear & Colorless & 1.006 & 8 & 24.69 & 108 & 86 & 16 & Neutrophilic \\
\hline & 4 & Clear & Colorless & 1.004 & 8 & 50 & 110 & 3 & 6 & Absent \\
\hline & 5 & Clear & Colorless & 1.006 & 7 & 38.6 & 105 & 310 & 70 & Monocytic \\
\hline & 6 & Clear & Colorless & 1.004 & 8 & 18.8 & 53 & 20 & 5 & Absent \\
\hline & 7 & Clear & Colorless & 1.008 & 8 & 16.2 & 28 & 3 & 1 & Absent \\
\hline & 8 & Clear & Colorless & 1.006 & 8 & 30.5 & 68 & 7 & 3 & Absent \\
\hline & 9 & Cloudy & $\begin{array}{l}\text { Light } \\
\text { yellow }\end{array}$ & 1.006 & 8 & 45.15 & 84 & 1,311 & 333 & Lymphocytic \\
\hline & 10 & Clear & Colorless & 1.006 & 6.5 & 39.13 & 80 & 70 & 24 & $\begin{array}{l}\text { Monocytic }(55 \%) \text { and } \\
\text { lymphocytic }(45 \%)\end{array}$ \\
\hline & 11 & Clear & Colorless & 1.006 & 8 & 23.4 & 69 & 9 & 2 & Absent \\
\hline \multirow[t]{2}{*}{ BoHV-5 } & 12 & Clear & Colorless & 1.006 & 8 & 15.89 & 61 & 8 & 9 & Absent \\
\hline & 13 & $\begin{array}{l}\text { Cloudy } \\
(++)\end{array}$ & Whitish & 1.008 & 8 & 117.5 & 50 & 58 & 304 & Monocytic \\
\hline \multirow[t]{3}{*}{ Conidiobolomycosis } & 14 & Clear & Colorless & 1.010 & 8 & ND & 50 & 2 & 5 & Absent \\
\hline & 15 & Cloudy & $\begin{array}{l}\text { Light } \\
\text { yellow }\end{array}$ & 1.006 & ND & 200 & ND & 1 & 20 & Neutrophilic \\
\hline & 16 & Clear & Colorless & 1.000 & ND & ND & ND & 6 & 4 & Absent \\
\hline
\end{tabular}

$\overline{\mathrm{ND}}=$ not determined, BoHV-5 = bovine herpesvirus 5.

Table 3. Results of cerebrospinal fluid analyses of 15 ruminants showing neurological signs due to bacterial diseases

\begin{tabular}{|c|c|c|c|c|c|c|c|c|c|c|c|}
\hline Disease & Case & Aspect & Color & Density & $\mathrm{pH}$ & $\begin{array}{l}\text { Proteins } \\
(\mathrm{mg} / \mathrm{dl})\end{array}$ & $\begin{array}{l}\text { Glucose } \\
(\mathrm{mg} / \mathrm{dl})\end{array}$ & $\begin{array}{c}\text { Erythrocytes } \\
(/ \mu \mathrm{L})\end{array}$ & $\begin{array}{l}\text { Nucleated } \\
\text { cells }(/ \mu \mathrm{L})\end{array}$ & Pleocytosis & Bacterial culture \\
\hline \multirow[t]{4}{*}{ Listeriosis } & 17 & Clear & Colorless & 1.008 & ND & ND & ND & 9 & 213 & Monocytic & ND \\
\hline & 18 & Cloudy & $\begin{array}{l}\text { Light } \\
\text { yellow }\end{array}$ & 1.005 & 8 & 400 & ND & 176 & 92 & Neutrophilic & $\begin{array}{l}\text { Listeria monocyto- } \\
\text { genes }\end{array}$ \\
\hline & 19 & Cloudy & Yellow & 1.008 & 8 & 360 & ND & 95 & 66 & Neutrophilic & L. monocytogenes \\
\hline & 20 & Clear & Colorless & 1.034 & 8 & 480 & 50 & 48 & 75 & Neutrophilic & L. monocytogenes \\
\hline \multirow[t]{6}{*}{$\begin{array}{l}\text { Suppurative } \\
\text { meningitis }\end{array}$} & 21 & $\begin{array}{l}\text { Cloudy } \\
(++)\end{array}$ & Opalescent & 1.012 & 8 & 107.1 & 27 & 5 & 7,470 & Neutrophilic & Escherichia coli \\
\hline & 22 & Cloudy & Reddish & 1.008 & 8 & 135 & 18.6 & 2,000 & 720 & Neutrophilic & ND \\
\hline & 23 & Purulent & Milky & ND & ND & ND & ND & ND & ND & ND & $\begin{array}{c}\text { Stenotrophomonas } \\
\text { sp. }\end{array}$ \\
\hline & 24 & Cloudy & $\begin{array}{l}\text { Light } \\
\text { yellow }\end{array}$ & 1.030 & ND & 300 & ND & 2,150 & 598 & Neutrophilic & Escherichia coli \\
\hline & 25 & Cloudy & $\begin{array}{l}\text { Light } \\
\text { yellow }\end{array}$ & 1.020 & ND & 200 & ND & 58 & 453 & Neutrophilic & ND \\
\hline & 26 & $\begin{array}{l}\text { Cloudy } \\
(++)\end{array}$ & Colorless & 1.016 & ND & ND & ND & 555 & 333 & $\begin{array}{l}\text { Monocytic } \\
\text { and neutro- } \\
\text { philic }\end{array}$ & ND \\
\hline \multirow[t]{5}{*}{ Abscesses } & 27 & Clear & Colorless & 1.006 & 7 & 18.5 & 20 & 13 & 3 & Absent & Proteus sp.** \\
\hline & 28 & Cloudy & Reddish & 1.014 & ND & 500 & ND & 72,000 & 50 & Neutrophilic & $\begin{array}{c}\text { Trueperella pyo- } \\
\text { genes }\end{array}$ \\
\hline & 29 & Clear & Colorless & 1.008 & ND & 412 & ND & 11 & 17 & Absent & \\
\hline & 30 & Cloudy & $\begin{array}{l}\text { Light } \\
\text { yellow }\end{array}$ & 1.010 & 7.5 & 300 & ND & 235 & 997 & Neutrophilic & $\mathrm{ND}^{*}$ \\
\hline & 31 & Clear & Colorless & 1.010 & 8 & 200 & ND & 3 & 1 & Absent & Streptococcus sp.** \\
\hline
\end{tabular}

ND = not determined; ${ }^{*}$ Gram positive bacilli type bacteria observed in histology, ${ }^{* *}$ bacteria cultured from vertebrae abscesses. 
presented increased density $\left(1,034 \mathrm{~kg} / \mathrm{m}^{3}\right)$ and protein $(480$ $\mathrm{mg} / \mathrm{dL}$ ), presence of fibrin clots, and neutrophilic pleocytosis (75 leukocytes $/ \mu \mathrm{L}$ ), despite no cranial nerve alterations. The difficulty in isolating the bacteria from CSF samples is notorious, and it is necessary to refrigerate the samples for several days to reduce false negative results (Mayhew 2009). Recently, culturing CSF samples or CNS fragments has been presented as a useful laboratory tool for making a conclusive diagnosis of L. monocytogenes meningoencephalitis in sheep (Câmara et al. 2014c).

Suppurative meningitis was diagnosed in six ruminants (Cases 21-26). In four young animals (two lambs - Cases 25 and 26; one calf - Case 23; and one goat kid - Case 24), the disease was associated with immunosuppression, which may be due to inadequate colostrum intake, malnutrition, or viral infection (Câmara et al. 2014a). The other cases occurred in a 5-month-old sheep (Case 21), as a consequence of a contaminated tail-docking wound, and an adult cattle (Case 22) in which the etiology remained undetermined. Cerebellar-medullary puncture of a 6-day-old crossbred calf with 4-day evolution of nervous signs contained a purulent material, and CSF analysis was impossible (Case 23). A CSF sample and CNS fragments were microbiologically cultured, revealing Stenotrophomonas sp. This bacterial genus is mainly responsible for meningitis in immunosuppressed or debilitated humans (Reddy et al. 2006), reinforcing the immunosuppression possibility (Fecteau \& George 2004). Three other young ruminants (Cases 24-26) presented cloudy-

Table 4. Results of cerebrospinal fluid analyses of 21 ruminants showing neurological signs caused by toxic disorders

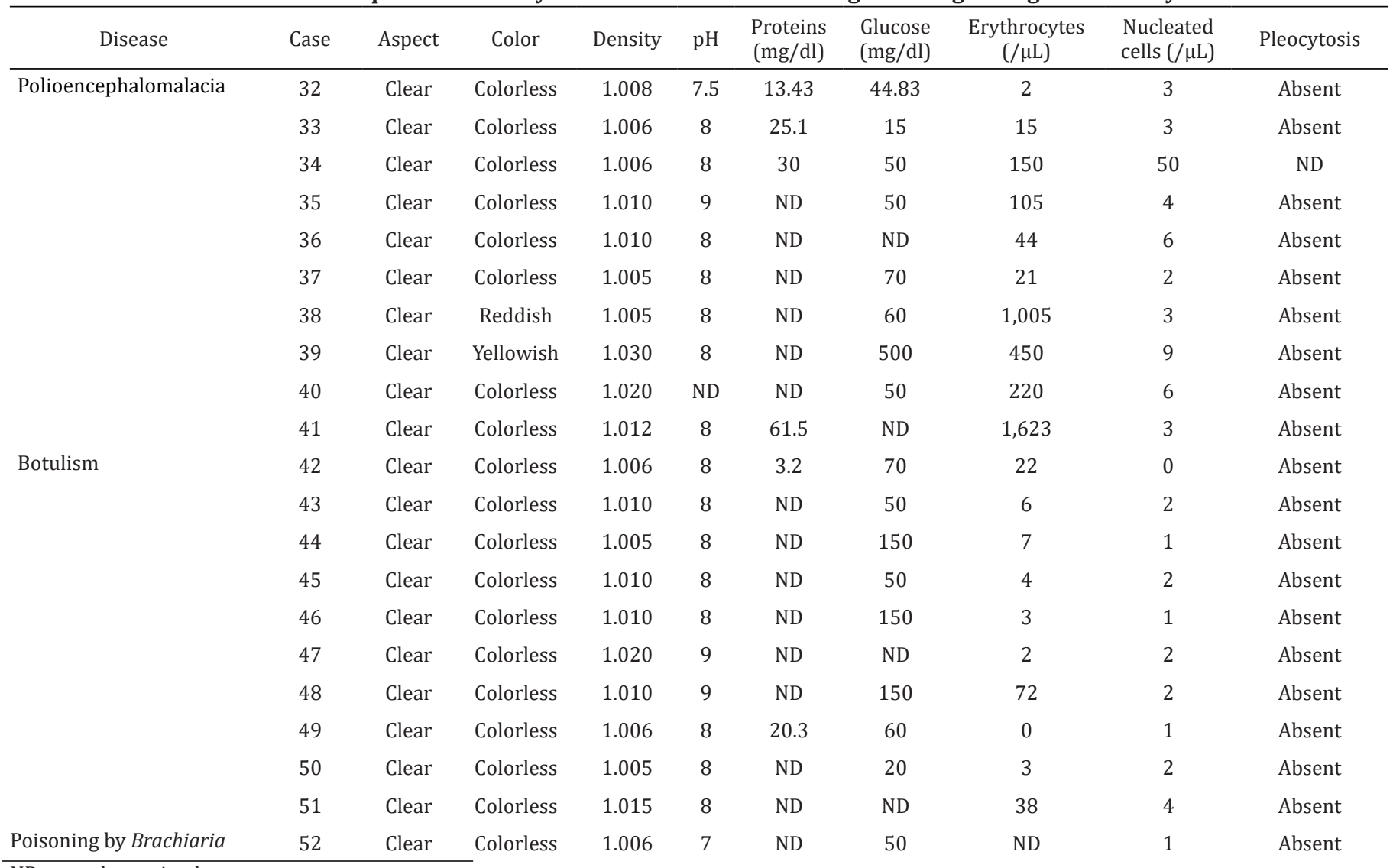

Table 5. Results of cerebrospinal fluid analyses of 6 ruminants showing neurological signs caused by traumatic (n=4) and congenital disorders $(n=2)$

\begin{tabular}{|c|c|c|c|c|c|c|c|c|c|c|}
\hline Disease & Case & Aspect & Color & Density & $\mathrm{pH}$ & $\begin{array}{l}\text { Proteins } \\
(\mathrm{mg} / \mathrm{dl})\end{array}$ & $\begin{array}{l}\text { Glucose } \\
(\mathrm{mg} / \mathrm{dl})\end{array}$ & $\begin{array}{c}\text { Erythrocytes } \\
(/ \mu \mathrm{L})\end{array}$ & $\begin{array}{l}\text { Nucleated } \\
\text { cells }(/ \mu \mathrm{L})\end{array}$ & Pleocytosis \\
\hline Atlanto-axial dislocation & 53 & Clear & Colorless & 1.006 & 8 & 43.9 & 45 & 85 & 26 & Monocytic \\
\hline C2-C3 fracture & 54 & Clear & Colorless & 1.008 & 7 & 35.9 & 93 & 645 & 12 & Monocytic \\
\hline T6-T8 fractures & 55 & Clear & Colorless & 1.006 & 8 & 21.0 & 53 & 3 & 2 & Absent \\
\hline Spinal cord compression & 56 & Cloudy $(+++)$ & Reddish & 1.012 & 8 & 118.3 & 31 & Countless & 3,555 & Monocytic \\
\hline Spinal lipomatosis & 57 & Clear & Colorless & 1.012 & 8.5 & 47.5 & 116 & 35 & 11 & Lymphocytic \\
\hline Cerebellar hypoplasia & 58 & Clear & Colorless & 1.008 & 7 & 17.77 & 95.45 & 39 & 3 & Absent \\
\hline
\end{tabular}


looking CSF with a light yellow coloration, presence of fibrin clots, increased density, and neutrophilic pleocytosis. These findings are consistent with those reported in sheep (Scott 2010) and cattle (Scott 2004, Stokol et al. 2009) with bacterial meningoenchephalitis, except for the protein concentration that is, in most cases, above 1g/dL (Fecteau \& George 2004, Mayhew 2009, Scott 2010). Another relevant aspect is to observe the presence of toxic or degenerate neutrophils, common in cases of bacterial infections; while parasitic infections may present non-degenerate and hypersegmented neutrophils, in addition to eosinophilia (Mayhew 2009). In two cases (Cases 21 and 24), microbiological assays yielded Escherichia coli, considered to be the most common Gramnegative meningeal pathogen in neonate cattle (Fecteau \& George 2004). In sheep and goats, E. coli, Pasteurella sp., Corynebacterium pseudotuberculosis, Streptococcus sp., and Trueperella pyogenes have already been cultured from clinical cases (Mayhew 2009).

Pituitary abscess syndrome (PAS), or basilar empyema, is a neurological disease characterized by the formation of abscesses in the vascular complex over the basosphenoid bone (Fernandes et al. 2000, Braun et al. 2017a). PAS was diagnosed in two calves (Cases 28 and 29) aged 8 and 11 months, associated with the use of a controlled suckling device and hematogenous dissemination from bronchopneumonia (Câmara et al. 2009). Herein, CSF analysis showed increased protein and mild neutrophilic pleocytosis (17 and 50 leukocytes $/ \mu \mathrm{L}$ ), while 12 cases of cattle with CNS abscesses averaged 12 leukocytes $/ \mu \mathrm{L}$ and protein below $425 \mathrm{mg} / \mathrm{dl}$. In other ruminants, CSF analysis may, however, be normal, indicating a non-suppurative response, or the CSF may be clearly purulent, with bacteria present (Mayhew 2009). Recently, a 22-month-old bull was diagnosed with PAS and revealed markedly increased, mixed pleocytosis $(2,437$ cells / $\mu \mathrm{L})$ and high protein concentration $(3.1 \mathrm{~g} / \mathrm{L})$ (Braun et al. 2017a). In one of the CSF aliquots (Case 28), microbiological assays yielded $T$. pyogenes, the most common bacteria in chronic suppurative lesions of the brain in cattle (Fernandes et al. 2000, Mayhew 2009). The treatment for PAS is usually considered ineffective, but favorable results have also been reported (Câmara et al. 2009, Braun et al. 2017a).

A sporadic case of leptomeningitis and thalamus abscess (Case 30) in a doe was recorded. CSF analysis revealed turbidity, yellowish coloration, and marked neutrophilic pleocytosis (997 leukocytes $/ \mu \mathrm{L}$ ). This doe presented parotideal caseous lymphadenitis one month earlier. Brain abscesses manifest as a chronic process, while suppurative leptomeningitis has an acute onset (Mayhew 2009), strongly suggesting that this case was secondary to caseous lymphadenitis, since CNS histology presented Gram-positive bacilli (Câmara et al. 2014a). Other cases presenting medullary signs secondary to abscesses compression were observed in a 6-month-old crossbreed calf (Case 27) and a goat (Case 31). CSF analysis in both cases were unremarkable. Necropsy revealed the presence of spinal cord compression by vertebral abscesses. Microbiological culture from the abscess contents yielded Proteus sp. and Streptococcus sp., respectively. CSF changes depend on the location of the abscess(es), but when the abscess(es) does not infiltrate the dura mater (pachymeningitis), the CSF may be unchanged (Braun et al. 2017b).
Of the 58 ruminants, 10 animals (17.2\%) were diagnosed with polioencephalomalacia (PEM). The disease occurred as sporadic cases (Cases 32-34, 36, and 41) and as outbreaks (Cases 35 and 37-40) affecting small ruminants and cattle. In most ruminants (Cases 32-38 and 41), PEM was correlated with high-fermentation carbohydrate diets. Such food management promotes the reduction of rumen $\mathrm{pH}$, leading to lactic acidosis, and consequent inhibition of thiaminproducing microorganisms, favoring the multiplication of thiaminase-producing bacteria (Haven et al. 1983), resulting in PEM clinical manifestations (Sant'Ana et al. 2009). The remaining animals (Cases 39 and 40) presented PEM lesions correlated with sulfur poisoning from water contaminated by petroleum (Batista et al. 2013). In CSF samples from thiamine-deficiency PEM, most ruminants presented all CSF parameters within reference values for cattle (Scott 2004) and sheep (Scott 2010). In five cases (50\%; Cases 35, 36, 39, 40 , and 41), CSF analysis showed density above the normal or in the upper limit $(\geq 1.010)$ of the physiological parameters. This finding is considered non-specific and of low precision for investigation of the cause of neurological diseases in ruminants (Scott 2004, 2010). Furthermore, the presence of increased density is an unusual finding in ruminants with PEM, since only the presence of normal protein concentrations and mild lymphocytic pleocytosis have been reported (Scott 2004, Mayhew 2009, Nagy 2017). As in the cases reported here, $75 \%$ of cattle with PEM in a previous report also showed no pleocytosis (Stokol et al. 2009); this finding was also described for PEM experimentally induced in calves by sulfur administration (Cunha et al. 2011). Ruminants poisoned by petroleum presented physical CSF alterations, such as a yellowish coloration (xanthochromia) and the presence of fibrin clots (Case 39). The former feature may be observed within hours of subarachnoid hemorrhage (Scott 2010), possibly caused by trauma; and it is consistent with a history of falls and the macroscopic findings of subdural hemorrhages in the CNS (Batista et al. 2013). Moreover, the presence of moderate protein increase, mild mononuclear pleocytosis, and xanthochromia are also described, particularly if there is already a CNS lesion (Mayhew 2009). Fibrin clots in the CSF are indicative of bacterial contamination (Câmara et al. 2014a); however, microbiological assays resulted negative, which may be explained by the increase in protein concentration (Stokol et al. 2009).

Seven cattle (Cases 42-48) and three sheep (Cases 49-51) were diagnosed with botulism (10 ruminants; $17.2 \%)$. These 10 outbreaks occurred on different farms from Northeastern (Câmara et al. 2014b) and Midwestern Brazil. In these ruminants, CSF analysis revealed a clear, colorless appearance, absence of fibrin clots, increased density $(\geq 1.010)$ in 6 of 8 cases (75\%), while leukocyte counts peaked at 4 leukocytes/ $\mu \mathrm{L}$. Such results are within the physiological limits for both species (Scott 2004, 2010). This finding was similar to those previously reported in cattle affected by botulism in São Paulo, Brazil (Lisbôa et al. 1996). These features are to be expected, since Clostridium botulinum toxins promote functional disorder at nerve synapses, where they compete with acetylcholine (Mayhew 2009). Conclusive diagnosis of these outbreaks of botulism was based on epidemiological and clinical findings and the absence of macro and microscopic lesions (Dutra et al. 2005), confirming the economic importance of the disease 
in Brazilian farms (Câmara et al. 2014b). The CSF findings found here presented similar results among ruminants with PEM and botulism. Therefore, we highlight the importance of correlating CSF findings with epidemiological, clinical, and pathological findings to ensure that a conclusive diagnosis is reached correctly.

One sheep (Case 52) was poisoned by Brachiaria sp. grass; the animal showed photosensitization and neurological signs, probably as a consequence of hepatic encephalopathy. CSF analysis showed no changes. Pathological examination revealed moderate jaundice distributed diffusely throughout the carcass, and the liver was enlarged (hepatomegaly), with brownish coloration and multifocal whitish spots. Brachiaria grasses are widely used in Brazil as the main food source for ruminants, even though it may cause hepatogenic photosensitization. The compounds responsible for Brachiaria toxicity are saponins, mainly protodioscin (Diamantino et al. 2018).

Four cases of spinal cord trauma were diagnosed: one sheep (Case 53) and three cattle (Cases 54-56). The sheep was attacked by dogs, and suffered cervical vertebral dislocation, whereas the cattle were found recumbent in the paddocks and the cause of trauma remained undetermined. A calf diagnosed with spinal cord compression (Case 56) presented cloudy and reddish CSF, with increased protein content $(118.3 \mathrm{mg} / \mathrm{dL})$, the presence of countless erythrocytes, and monocytic pleocytosis. Although CSF from trauma patients may present these features (Mayhew 2009), it is worth emphasizing the importance of not allowing blood contamination of the CSF. Such an error could change the composition of the CSF, especially the protein concentration and cellularity (Câmara et al. 2011). Nevertheless, monocytic pleocytosis was also present in two other cattle (Cases 53 and 54), in which CSF collection was more successful. Therefore, monocytic pleocytosis might be observed in ruminants with spinal compression after short-term survival. On the other hand, a cow diagnosed with a vertebral fracture (Case 55) did not show any change in the CSF. Collection and analysis of CSF from animals suffering from spinal cord trauma is valuable for ruling out other causes of acute spinal cord disease, such as viral, verminous, and protozoal myeloencephalitis (Mayhew 2009). In fact, increases in proteins concentrations $(>0.39 \mathrm{~g} / \mathrm{L})$ and nucleated cell counts $(>4.5$ cells $/ \mu \mathrm{L})$ in the CSF of recumbent cows have been linked to spinal cord injury (Achard et al. 2017) and to decreased short-term survival (Bilodeau et al. 2018). Accordingly, firm evidence of subarachnoid hemorrhage may not always be found on analysis of CSF in spinal cord trauma (Mayhew 2009), as in our cases.

Two cases of congenital diseases in calves were evaluated; one was a case of spinal lipomatosis (Case 57) and another was a case of cerebellar hypoplasia (Case 58). These cases occurred on different dairy farms, and no other congenital diseases had previously been reported for these herds. The first case (Case 57) presented increased protein concentration $(47.5 \mathrm{mg} / \mathrm{dL})$ and slight lymphocytic pleocytosis. On the other hand, the CSF findings of the latter (Case 58) was unremarkable. Increased protein and nucleated cell count in the CSF have also been reported earlier in a calf showing neural tube defects (Cagnotti et al. 2019). Congenital malformations in ruminants can have various causes, such as teratogenic chemicals (Panter \& Stegelmeier 2011), genetic factors (Cagnotti et al. 2019), and some viruses (Agerholm et al. 2015). It was not possible to determine the etiology in these two cases in this study.

\section{CONCLUSIONS}

The findings of cerebrospinal fluid (CSF) analysis from ruminants with signs of neurological disease described here confirmed that pleocytosis (an increase in CSF cellularity) was associated with infectious diseases. However, no CSF changes may be observed in rabies, as seen in several cases in the present study.

The changes described in the number of nucleated cells and differential cell count are usually signs of bacterial infection, with an elevation of polymorphonucleated neutrophilic granulocytes in diseases involving purulent processes (Scott 2004, Câmara et al. 2014a), as observed here in cases of meningoencephalitis, suppurative meningitis, abscesses, myelitis, and in a case of conidiobolomycosis. On the other hand, CSF usually remains unchanged in toxic, metabolic, degenerative, and neoplastic diseases (Stokol et al. 2009), as in the reported cases of botulism and Brachiaria sp. poisoning.

In PEM, protein increases and mild mononuclear pleocytosis have been observed in CSF (Scott 2004, Mayhew 2009), while $60 \%$ of our cases presented elevated density as the only alteration.

Conflict of interest statement.- The authors declare that there are no conflicts of interest.

\section{REFERENCES}

Achard D., Francoz D., Grimes C., Desrochers A., Nichols S., Babkine M. \& Fecteau G. 2017. Cerebrospinal fluid analysis in recumbent adult dairy cows with or without spinal cord lesions. J. Vet. Intern. Med. 31(3):940-945. <http://dx.doi.org/10.1111/jvim.14705> <PMid:28382682>

Agerholm J.S., Hewicker-Trautwein M., Peperkamp K. \& Windsor P.A. 2015 Virus-induced congenital malformations in cattle. Acta Vet. Scand. 57(1):54 <http://dx.doi.org/10.1186/s13028-015-0145-8> <PMid:26399846>

Batista J.S., Câmara A.C.L., Almeida R.D., Olinda R.G., Silva T.M.F. \& SotoBlanco B. 2013. Poisoning by crude oil in sheep and goats. Revta Med. Vet. 164(11):517-520.

Batista J.S., Rodrigues C.M., García H.A., Bezerra F.S., Olinda R.G., Teixeira M.M. \& Soto-Blanco B. 2011. Association of Trypanosoma vivax in extracellular sites with central nervous system lesions and changes in cerebrospinal fluid in experimentally infected goats. Vet. Res. 42(1):63. <http://dx.doi. org/10.1186/1297-9716-42-63><PMid:21569364>

Bilodeau M.E., Achard D., Francoz D., Grimes C., Desrochers A., Nichols S. Babkine M. \& Fecteau G. 2018. Survival associated with cerebrospinal fluid analysis in downer adult dairy cows: A retrospective study (20062014). J. Vet. Intern. Med. 32(5):1780-1786. <http://dx.doi.org/10.1111/ jvim.15305><PMid:30216558>

Braun U., Gerspach C., Kühn K., Bünter J. \& Hilbe M. 2017b. Abscess of the cervical spine secondary to injection site infection in a heifer. Acta Vet. Scand. 59(1):10. <http://dx.doi.org/10.1186/s13028-017-0278-z> <PMid:28143552>

Braun U., Malbon A., Kochan M., Riond B., Janett F., Iten C. \& Dennle M. 2017a. Computed tomographic findings and treatment of a bull with pituitary gland abscess. Acta Vet. Scand. 59(1):8. <http://dx.doi.org/10.1186/ s13028-017-0276-1> <PMid:28086988>

Cagnotti G., Sammartano F., Bertone I., Capucchio M.T., Nicola I., Sacchi P. Bellino C. \& D'Angelo A. 2019. Imaging and genetic investigations of neural tube defect in a calf: case report and review of the literature. J. Vet. Diagn. Invest. 31(2):228-234. <http://dx.doi.org/10.1177/1040638718823037> <PMid:30852979>

Câmara A.C.L., Borges J.R.J., Godoy R.F., Moscardini A.R.C., Mustafa V.S., Castro M.B., Ximenes F.H.B., Paludo G.R., Perecmanis S. \& Drummond V.O. 2009. 
Síndrome do abscesso pituitário em bezerros na Região Centro-Oeste. Pesq. Vet. Bras. 29(11):925-930. <http://dx.doi.org/10.1590/S0100736X2009001100011>

Câmara A.C.L., Soto-Blanco B., Batista J.S., Vale A.M., Feijó F.M.C. \& Olinda R.G. 2011. Rhinocerebral and rhinopharyngeal conidiobolomycosis in sheep. Ciência Rural 41(5):862-868. <http://dx.doi.org/10.1590/S010384782011005000058>

Câmara A.C.L., Vale A.M., Batista J.S., Feijó F.M.C. \& Soto-Blanco B. 2014a Suppurative intracranial processes in 15 domestic ruminants. Pesq. Vet. Bras. 34(5):421-426. <http://dx.doi.org/10.1590/S0100-736X2014000500006>

Câmara A.C.L., Oliveira C.M.M., Vale A.M., Batista J.S. \& Soto-Blanco B. 2014b. Epidemiologia, sinais clínicos, achados laboratoriais e patológicos em oito surtos de botulismo em bovinos no Rio Grande do Norte. Acta Sci. Vet. 42:1200.

Câmara A.C.L., Olinda R.G., Batista J.S., Feijó F.M.C. \& Almeida R.D. 2014c Listeriose em ovinos associada ao consumo de silagem no Rio Grande do Norte. Revta Bras. Ciênc. Vet. 21(1):19-22. <http://dx.doi.org/10.4322/ rbcv.2014.023>

Cunha P.H.J., Badial P.R., Cagnini D.Q., Oliveira-Filho J.P., Moares L.F., Takahira R.K., Amorim R.L. \& Borges A.S. 2011. Polioencefalomalacia experimental em bovinos induzida por toxicose por enxofre. Pesq. Vet. Bras. 31(1):41-52. <http://dx.doi.org/10.1590/S0100-736X2011000100007>

Della Libera A.M.P., Leal M.L., Gregory L., Silva D.Y.R., Unruh S.M., Birgel-Júnior E.H. \& Benesi F.J. 2004. Cervical diskospondylitis in a calf: clinical, radiographic, and necroscopy findings. Can. Vet. J. 45(8):700-701. <PMid:15368748>

Diamantino G.M.L., Biscoto G.L., Pedroza H.P., Amorim R.N.L., Keller K.M., Melo M.M. \& Soto-Blanco B. 2018. Liquid chromatography coupled to quadrupole time-of-flight mass spectrometry (QTOF/MS) assay for quantification of protodioscin in Brachiaria grasses. Toxicon 155:61-65. <http://dx.doi.org/10.1016/j.toxicon.2018.10.008> <PMid:30347196>

Dutra I.S., Döbereiner J. \& Souza A.M. 2005. Botulismo em bovinos alimentados com cama de frango. Pesq. Vet. Bras. 25(2):115-119. <http://dx.doi.org/10.1590/S0100-736X2005000200009>

Fecteau G. \& George L.W. 2004. Bacterial meningitis and encephalitis in ruminants. Vet. Clin. N. Am., Food Anim. Pract. 20(2):363-377. <http:// dx.doi.org/10.1016/j.cvfa.2004.03.002 ><PMid:15203230>

Fernandes C.G., Schild A.L., Riet-Correa F., Bialardi C.E.G. \& Stigger A.L. 2000. Pituitary abscess in young calves associated with the use of a controlled suckling device. J. Vet. Diagn. Invest. 2000. 12(1):70-71. <http://dx.doi. org/10.1177/104063870001200114 > <PMid:10690781>

Galiza G.J.N., Silva M.L.C.R., Dantas A.F.M., Simões S.V.D. \& Riet-Correa F. 2010. Doenças do sistema nervoso de bovinos no semiárido nordestino. Pesq. Vet. Bras. 30(3):267-276. <http://dx.doi.org/10.1590/S0100736X2010000300014>

Haven T.R., Caldwell D.R. \& Jensen R. 1983. Role of predominant rumen bacteria in the cause of polioencephalomalacia (cerebrocortical necrosis) in cattle. Am. J. Vet. Res. 44(8):1451-1455. <PMid:6625295>

Isernhagen A.J., Cosenza M., Costa M.C., Médici K.C., Balarin M.R.S., Bracarense A.P.F.R.L., Alfieri A.A. \& Lisbôa J.A.N. 2011. Asymptomatic encephalitis in calves experimentally infected with bovine herpesvirus-5. Can. Vet. J. 52(12):1312-1318. <PMid:22654135>
Lisbôa J.A.N., Isernhagen A.J., Borges A.S., Amorim R.M., Balarin M.R.S., Lunardi M. \& Alfieri A.A. 2009. Hematological and cerebrospinal fluid changes in cattle naturally and experimentally infected with the bovine herpesvirus 5. Braz. Arch. Biol. Technol. 52:69-76. <http://dx.doi.org/10.1590/S1516$89132009000700010>$

Lisbôa J.A.N., Kuchembuck M.R.G., Kohayagawa A., Bomfim S.R.M., Santiago A.M.H. \& Dutra I.S. 1996. Resultados de patologia clínica e dosagens de elementos minerais em bovinos acometidos pelo botulismo epizoótico no estado de São Paulo. Pesq. Vet. Bras. 16(4):91-97.

MacFaddin J.F. 2000. Biochemical Tests for Identification of Medical Bacterial. Lawrence McGrew, Lippincott Williams and Wilkins, Philadelphia. 912p.

Mayhew I.G.J. 2009. Large Animal Neurology. 2nd ed. Chichester: WileyBlackwell. 464p.

Moreira I.L., Sousa D.E., Ferreira-Junior J.A., Castro M.B., Fino T.C., Borges J.R.J., Soto-Blanco B. \& Câmara A.C.L. 2018. Paralytic rabies in a goat. BMC Vet. Res. 14(1):338. <http://dx.doi.org/10.1186/s12917-018-1681-z> <PMid:30419906>

Nagy D.W. 2017. Diagnostics and ancillary tests of neurologic dysfunction in the ruminant. Vet. Clin. N. Am., Food Anim. Pract. 33(1):9-18. <http:// dx.doi.org/10.1016/j.cvfa.2016.09.002><PMid:28166937>

Panter K.E. \& Stegelmeier B.L. 2011. Effects of xenobiotics and phytotoxins on reproduction in food animals. Vet. Clin. N. Am., Food Anim. Pract. 27(2):429446. <http://dx.doi.org/10.1016/j.cvfa.2011.02.010><PMid:21575779>

Queiroz G.R., Pereira P.F.V., Flaiban K.K.M.C., Santis G.W.D., Alfieri A.A. \& Lisbôa J.A.N. 2018. Cerebrospinal fluid changes in cattle with rabies or with BoHV-5 meningoencephalitis and its correlation with the severity of CNS inflammatory process. Res. Vet. Sci. 118:389-394. <http://dx.doi. org/10.1016/j.rvsc.2018.03.015> <PMid:29684815>

Reddy P., Das S., Chandler J.P. \& Noskin G.A. 2006. Stenotrophomonas maltophilia meningitis treated with moxifloxacin: a case report and review of the literature. Infect. Dis. Clin. Pract. 14(3):173-176. <http://dx.doi.org/10.1097/01.idc.0000194059.14537.e5>

Ribas N.L.K.S., Carvalho R.I., Santos A.C., Valençoela R.A., Gouveia A.F., Castro M.B., Mori A.E. \& Lemos R.A.A. 2013. Doenças do sistema nervoso de bovinos no Mato Grosso do Sul: 1.082 casos. Pesq. Vet. Bras. 33(10):1183-1194. <http://dx.doi.org/10.1590/S0100-736X2013001000003>

Sanches A.W.D., Langohr I.M., Stigger A.L. \& Barros C.S.L. 2000. Doenças do sistema nervoso central em bovinos do Sul do Brasil. Pesq. Vet. Bras. 20(3):113-118. <http://dx.doi.org/10.1590/S0100-736X2000000300005>

Sant'Ana F.J.F., Lemos R.A.A., Nogueira A.P.A., Togni M., Tessele B. \& Barros C.S.L. 2009. Polioencefalomalacia em ruminantes. Pesq. Vet. Bras. 29(9):681-694. <http://dx.doi.org/10.1590/S0100-736X2009000900001>

Scott P.R. 2004. Diagnostic techniques and clinicopathologic findings in ruminant neurologic disease. Vet. Clin. N. Am., Food Anim. Pract. 20(2):215230. <http://dx.doi.org/10.1016/j.cvfa.2004.02.004><PMid:15203223>

Scott P.R. 2010. Cerebrospinal fluid collection and analysis in suspected sheep neurological disease. Small Rumin. Res. 92(1/3):96-103. <http://dx.doi.org/10.1016/j.smallrumres.2010.04.009>

Stokol T., Divers T.J., Arrigan J.W. \& McDonough S.P. 2009. Cerebrospinal fluid findings in cattle with central nervous system disorders: a retrospective study of 102 cases (1990-2008). Vet. Clin. Pathol. 38(1):103-112. <http://dx.doi.org/10.1111/j.1939-165X.2008.00094.x><PMid:19228366> 